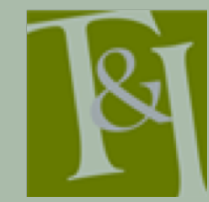

The International Journal for Translation \& Interpreting Research trans-int.org

\section{The cautiously pragmatic translation policy in Estonia}

\author{
Luc van Doorslaer \\ University of Tartu, Estonia \\ KU Leuven, Belgium \\ Stellenbosch University, South Africa \\ luc.vandoorslaer@kuleuven.be
}

\section{Terje Loogus}

University of Tartu, Estonia

terje.loogus@ut.ee

DOI: $10.12807 /$ ti.11222.2020.a06

\begin{abstract}
Translation policy is never neutral, as it does not only take into account linguistic and cultural elements, but also aspects of political and economic power. Situations of unequal power relationships between states or language areas make especially interesting objects for study. The Republic of Estonia has been one such a case since its regained independence in 1991. Estonia has developed a language and translation policy prioritizing Estonian, due to the demographic changes during the period of the Soviet occupation as well as recent globalization developments. The cases of two institutional websites (those of the President of the Republic and the University of Tartu) show how this prioritized viewpoint plays out in translation practice: it allows for pragmatically accommodating both an international audience and the minority of Russian language speakers, albeit not to the same extent.
\end{abstract}

Keywords: language policy; translation management; translation practices; translation beliefs; linguistic power relationships

Over the past decade, the discipline of Translation Studies has devoted more attention to the importance of translation policies in situations related to political and economic power relationships. The first part of this article offers an overview of some relevant previous research, before applying it to the case of Estonia. A brief explanation of the history and the demographic situation of the country serves to introduce the existing language and/or translation policy as well as relevant legislation. Two test cases investigating the materialization of translation policy in official websites subsequently illustrate the application by agencies in the public domain. The institutional cases are the homepages of the President of the Republic and of the University of Tartu, the oldest and leading university of the country. The conclusion seeks to align the findings with the existing literature on translation policy.

\section{Translation policy research}

Existing translation policy research often focuses on cultural matters, particularly when dealing with unequal power relationships between languages. This not only underpins the research on translation flows as inspired by the 
sociologically oriented approaches of Johan Heilbron and Gisèle Sapiro (for instance Heilbron \& Sapiro, 2007; van Es \& Heilbron, 2015; Sapiro, 2016). A significant number of case studies also thematize cultural inequalities and their relationship with translation policy. For instance, culture planning in smaller cultures is the topic of Martina Ožbot (2012), who describes the development of 'low code' Slovene culture beside 'high code' German culture. Translation from Slavic cultures was encouraged to actively change the existing cultural and linguistic power relationships. Cultural dominance patterns can be actively opposed by importing innovative, but similarly strong literary influences. Another example of such import by a smaller culture is the attempt of the 'Young Estonia' movement to extend the influence of Romance literature in early 20th century Estonia (see Monticelli 2015). However, the policy has also been adopted by larger language areas, which aimed to renew their cultural sources. This was for instance the case of Germany in the late 19th and early 20th century. It tried to move away from the dominant cultural influence of France by importing Scandinavian and Nordic literature on a large scale by means of translation (see van Doorslaer, 2006).

Ožbot's approach is an interesting case in point, as she explicitly relates the culture planning policy to political and economic power relationships: "translating is never a neutral act, but a process in which relations of linguistic, cultural, political and economic power are at play" (2012, p. 108). Whereas such cultural power struggles between larger language areas are never existential, this is much more the case in unequal power relationships. Ožbot mentions the example of bilingual environments such as Ireland, "in which the two interacting languages were extremely unequal in terms of their power relations" (108) and translating could not be considered a neutral act. Cultural and language policy are closely interwoven through translation or non-translation in such cases.

Indeed, even when a (non-)translation policy does not specifically aim to achieve political goals, it can be highly ideologically and politically sensitive. Christina Schäffner (2016/2008) deals with the 2006 discussion in the UK media about the costs and the political desirability of providing translation in immigration matters. Within our discipline, translation practice and translation policy are usually associated with positive terms such as support and bridgebuilding. However, the dominant discourse in the UK media discussion was totally different. Besides being criticized for the high costs involved, highly generous translation facilities for immigrants were also associated with a barrier to learning English, a danger to social cohesion and a higher risk of failed integration. The whole discourse was "rather a discourse about immigration, integration, citizenship, national identity" (Schäffner, 2016, p. 252).

A central element in almost all language policies is the decision whether to translate or not, or what to translate or not. As a consequence, every state or institution with a multilingualism policy is in practice also dealing with a translation policy (see also Meylaerts, 2011, p.744). Such policies and practices can be either top-down, imposed by authorities, or bottom-up, generated by everyday multilingual situations in contemporary cities, for instance - for more examples of both types, see van Doorslaer (2018). Top-down policies in particular are often associated with the attempts of states to boost national integration policies, both from a cultural and a political point of view. Translation in such cases is used as an agent defending hegemonic national interests, as stated by Gipper \& Dizdar (2015, p. $\left.8^{\mathrm{i}}\right)$. However, national interests

i The full German quote reads as follows: "Die Rede ist vom weiten Feld der Übersetzungspolitiken, das hier vor allem da interessiert, wo Nationalstaaten Translation \& Interpreting Vol. 12 No. 2 (2020) 
do not necessarily mean homogenizing a state linguistically or culturally. State borders can be used or abused to minoritize a language group that is all but minoritarian at a different level.

This is for instance the case for the small German-language population in Belgium - German being the third official language in Belgium after Dutch and French. Although there exists a legal framework guaranteeing many rights, the German-speaking Belgians are often dissatisfied about its "non-implementation in (some) governmental and linguistic practice(s)" (van Doorslaer, 2018, p. 53). National borders (of Belgium, in this case) apparently can lead to an insufficient implementation of language and translation rights even for the speakers of the largest linguistic community in the European Union, as the German-speaking area of Belgium borders on areas housing almost 100 million other German speakers in Europe, namely in Germany, Switzerland, Austria and Luxemburg. This example shows the relative status of power relationships between languages, because they are co-determined by the language and translation policy of the state in which they operate. The case below also is to be understood within such a complex power framework. Although Estonian is the majority's (and only official) language within the Republic of Estonia, the language and translation policy toward the large Russian-language minority cannot be discussed without taking into account the position of neighboring Russia. In this sense, we can make very similar cases for Estonia(n) and Latvia(n). Translation policy also especially plays a role in this process in Central and Eastern Europe, where "the dynamics of bordering and rebordering" (Rumford, 2006, p. 155) is ongoing after the collapse of the Soviet Union.

Drawing on Spolsky's work on language policy, Gabriel González Núñez (2016) distinguishes three levels of translation policy. We will apply his taxonomy when analyzing and assessing the case studies discussed in this article: translation management: explicit top-down policy referring to the decisions about use or non-use of translation; translation practice: practices as a result of the above-mentioned policy, but also more implicit bottom-up practices based on the needs; translation beliefs: beliefs of a community about the value of translation under specific circumstances.

The next section briefly describes the historical and demographic circumstances of Estonia over the past century, before investigating two institutional websites in more detail, using González Núñez' translation policy terminology.

\section{Estonia: history and demographic situation in brief}

Estonia is a country in Northeastern Europe with a population of 1.3 million people. After centuries of Danish, Swedish, German, and Russian rule, Estonia attained independence from the Russian Empire in 1918. In 1940 it was forcibly incorporated into the USSR and regained its freedom only in 1991, with the collapse of the Soviet Union. Languages spoken in Estonia reflect the ethnic groups living in the country, and have therefore changed according to the sociopolitical situation. In 1919, Estonian, a Uralic language related to Finnish, became the state language of the newly independent country. During the Soviet occupation and as a result of russification policy, the proportion of Estonians in

versuchen, nationale Integrationsprozesse kulturell oder auch ganz konkret politisch zu steuern und wo in deren Rahmen Übersetzungen zu Agenten hegemonialer nationaler Interessen werden. “ 
the overall population fell from $97.3 \%$ in 1945 to $61.5 \%$ in 1989 (Rannut, 2004). Russian was made the second language in education, and the first in several functional spheres, such as industrial plants, factories, offices, state institutions and service bureaus, which were created in parallel with the Estonian ones (Rannut, 2004). The Estonian language was reinstated as the constitutional state language in 1988. After regaining independence in 1991, the greatest change in the language policy was related to the status and use of Russian in the Estonian education system: learning Estonian is compulsory for all students, while at the level of higher education, the language of tuition is mainly Estonian, with diminishing options for studying in Russian (Soll, Salvet, \& Masso, 2015, p. 223f.). Russian is still widely used in some parts of Estonia (mostly in the Northeastern part of the country and in some parts of the capital city Tallinn), but has no official status.

According to the results of the 2011 Population and Housing Census, the largest ethnic groups are Estonians (68.7\%), Russians (24.8\%), Ukrainians $(1.7 \%)$, Belarusians and Finns (both less than 1\%). Estonian as the official language is the native language of $68.5 \%$ of the population. The most prevalent minority native language is Russian, spoken by $29.6 \%$ of the population. There is a total of 25 languages with over one hundred native speakers in Estonia (Statistics Estonia, 2012). The majority of the population of Estonia is multilingual, speaking at least one foreign language in addition to their mother tongue (usually a more widely spoken language, such as Russian, English or German). European integration has increased the interest in English among Estonian and Russian speakers, which has given rise to the English language in the Estonian education system and in Estonian society at large.

\section{Language/translation policy and legislation}

Since Estonia regained its independence, language legislation has developed inconsistently. Language use and language management are described in various laws, most clearly in the Constitution of the Republic of Estonia (1992), the Language Acts (1995 and 2011), the Development Plans of the Estonian Language (2004-2010 and 2011-2020), and the Estonian Foreign Languages Strategy (2009-2017). Translation policy as such has not been legislated in Estonia; the use of foreign languages and translation has been implicitly included in all of the above-mentioned laws and legislations. The implicit presence of translation policy is discussed in more detail in the paragraphs below.

At the very general level, the principles of language policy are stated in the Constitution of the Republic of Estonia (1992). The preamble and the Article 6 of the Constitution stipulate that Estonia has one state language -Estonianwhich has to be preserved and developed by all people and institutions of Estonia. Although Estonian is the official language of government agencies and local authorities, other languages and different mother tongues are also accepted. The use of foreign languages (and the implicit presence of translation) is mentioned in Article 52 of the Constitution, which stipulates that "the use of foreign languages, including the languages of national minorities, in government agencies, in courts and in pre-trial procedure is provided by law".ii

ii All quotes from laws in this article use the English text as digitally available in the State Gazette. The Electronic State Gazette (Riigi Teataja) is the central database and official online publication for Estonian legislation. Since 2010, all national legal acts are made public only in electronic form in Estonia. The English translations published Translation \& Interpreting Vol. 12 No. 2 (2020) 
This article protects the interests of minorities and gives certain local authorities the right to decide on the use of the language in internal affairs. The Constitution of the Republic of Estonia has been translated into English and Russian. The English version is digitally available via the State Gazette. The Russian translation was published on the Legal Aid webpage of Eesti Õigusbüroo OÜ.iii

The most important legislative act concerning the language (and translation) policy in Estonia is the Language Act. It regulates the use of the Estonian language and foreign languages in oral and written administration, public information and service. According to subsection 8(1) of the current Language Act (2011), "[e]veryone has the right to access the public administration in the Estonian language in oral or written form in state agencies, including the foreign representations of Estonia, local government authorities, at the offices of notaries, bailiffs and sworn translators and their bureaus, cultural autonomy bodies and other agencies, companies, non-profit associations and foundations registered in Estonia." The words translate, translation and translator are mentioned 24 times across 10 sections. As the purpose of the Act is to ensure the use of the Estonian language as the main language for communication in all spheres of public life, the word translation mostly means translation from a foreign language into Estonian. Regarding translation policy, the most relevant are sections 12, 16, 18, 34 and 35. Section 12 "Access to public administration in foreign languages" regulates the role of translation in any communication with a state agency or local government authority and stipulates: "If an application, request or other document submitted to a state agency or local government authority is in a foreign language, the agency has the right to require the person who submits the document to submit the translation of the document into Estonian, [...]". Translation is also mentioned in section 16 "Language of information", where it says in subsection 16(2): "The translation of the text into a foreign language may be added to public signs, signposts, business type name and outdoor advertisements" and in subsection 16(5): "At public events the organiser shall ensure the translation into Estonian of the essential information in a foreign language." Section 18 "Translation of foreign language text of audio visual works, television and radio programmes and advertisements" stipulates: "Upon public performance and transmission of audio visual works, including programmes and advertisements, the provider of the audio visual media service or a company shall ensure that a foreign language text shall be accompanied by an adequate translation into Estonian in form and content". Sections 34-37 consider violations of requirements for the use of the Estonian language and their consequences. The Language Act has also been translated into English and published in the State Gazette. The Russian translation is available on the Legal Aid webpage of Eesti Õigusbüroo OÜ.

in the State Gazette are unofficial texts - they do not have legal force and one cannot rely on them in judicial or any other official proceedings. In Estonia, legislation has legal force only in Estonian. Retrieved from https://www.riigiteataja.ee/en/, accessed 26.12.2018

iii Eesti Õigusbüroo OÜ, in cooperation with the Ministry of Justice, provides legal assistance free of charge and under favorable terms to people residing in Estonia. In cooperation with the legal aid portal juristaitab.ee, 52 Russian translations of the law have been made available in the State Gazette. The translations of the laws are for informational purposes only and have no legal effect. Retrieved from https://www.juristaitab.ee/en, accessed 28.12.2018. 
Strategic planning of the development of the Estonian language was begun in 1998 by the Ministry of Education. In 2004, the Government of the Republic of Estonia adopted the first Development Strategy of the Estonian Language 2004-2010 (DSEL) which covered four areas: Estonian as the native language, Estonian as the second language, Estonian abroad, and multilingualism, including foreign languages. The follow-up document, the Development Plan of the Estonian Language 2011-2017 (DPEL), was prepared by the Ministry of Education and Research, and adopted in 2009. In 2018, the government decided to extend the DPEL until the end of 2020, and started to prepare the Estonian Language Development Plan 2021-2035. The DSEL was translated into English, Russian, Finnish, and Hungarian (DPEL, 2011, p. 7). The DPEL is available both in print and on the Internet in Estonian and in Englishiv.

The current Development Plan of the Estonian Language (DPEL) is a strategic document in the language domain. It ensures the functioning of the Estonian language as the state language in all spheres of life as well as the teaching, research, development, and protection of the Estonian language. The main objective of the DPEL is to provide a uniform strategic and legal basis for the sustainable development of the Estonian language (DPEL, 2011, p. 8). Translation is mentioned in only a few specific cases: translation in court proceedings, translation of information provided to consumers, the promotion of translation studies, the development of CAT tools and machine translation, the training of interpreters and translators. The most relevant parts of the DPEL related to translation matters are quoted below (emphasis by the authors):

- Estonian is also the language of court proceedings; legal acts regulate the use of other languages in court proceedings, as well as translation of documents and the use of an interpreter. The Consumer Protection Act stipulates that any information provided to the consumer has to be presented in Estonian; an Estonian-language translation is required for instruction manuals in a foreign language. (p. 18-19)

- Study of language contacts and language change: to promote translation studies (p. 31);

- Measure 3: Development of the language-technological support for the Estonian language. Actions: to work out modules of a translator's workbench, terminologist's workbench, and lexicographer's workbench, which could be modified if necessary; to create a machinetranslation system, where all existing devices for the processing of Estonian are adapted for the needs of machine translation; to develop large-scale parallel corpora for the needs of statistical machine translation (EU documents, major areas of international communication for Estonian scientists). (p. 35-37)

- It is important for the development of the Estonian language that the Estonian language should be well represented both in Europe and around the world (including through qualified interpreters and translators, academic studies of the Estonian language abroad, and various types of cooperation in language matters), as well as good Estonian and foreign-language proficiency among Estonian residents. (p. 65)

- Estonian institutions of higher education train interpreters and translators; according to estimates, the number of interpreters and

iv English translation by Enn Veldi. Retrieved from https:/www.hm.ee/sites/ default/files/eestikeelearengukavainglise.indd_.pdf, accessed 28.12.2018. 
translators is insufficient, but there is no accurate survey of needs. (p. 66)

- Measure 11: development of the Estonian language in the context of foreign languages and ensuring its international representation. Action: to determine the need for interpreters and translators and to train them in the required numbers. (p. 67)

The aim of the development plan is to ensure the preservation of the Estonian language, whereas foreign languages and translation are mentioned mostly in the context of academic studies, the international representation of the Estonian language or in the sphere of public administration.

The purpose of the measures of the Estonian Foreign Languages Strategy 2009-2015 (extended until 2017) is to provide Estonian people with better opportunities in a globalizing world and to increase their competitiveness in the labor market. Interestingly, this strategy is only available in the Estonian language. The Strategy comprises thematic principles as well as guidelines for foreign language learning, teaching and assessment. The learning of foreign languages has always been stressed in Estonian public discourse, but this is the first document that deals with foreign language policy and foreign language learning at government level. The goals of the Estonian Foreign Languages Strategy are to stimulate the motivation of Estonian residents to learn foreign languages, to offer different opportunities for foreign language learning and to enhance the quality of language teaching. Translation as such plays a relatively marginal role in this document and only concerns the following issues: the importance of the training of language professionals (including translators and interpreters) at universities (p. 9), the importance of setting criteria for foreign language skills at different jobs (e.g. sworn translators) (p. 10) and to conduct research in the area of foreign languages (including translation studies) (p. 21). In brief, translation is only mentioned with regard to the learning and teaching of foreign languages, as well as research in this field. Such a limited view on translation as a by-product of foreign language learning reflects the - for modern Translation Studies, very old-fashioned - view that translation skills are no different from foreign language skills, or that the knowledge of a foreign language equals translation skills.

\section{Cases of official language and translation policy}

The above-described principles of translation policy will now be examined by looking at their implementation in real life. We have selected and analyzed the homepages of two agencies of public life as test cases: the homepage of the President of the Republic of Estonia and the homepage of the University of Tartu, the oldest and most prominent university of Estonia. As institutionalized agencies, these cases are relevant for assessing how the official language and translation policy is adopted in practice.

\subsection{The President's website}

The current President of the Republic of Estonia, Kersti Kaljulaid, was elected by Parliament on 3 October 2016. The constitution stipulates various tasks for the President, both in domestic and foreign policy. In the field of foreign policy, the President mostly fulfils representational duties. The more significant duties of the President relate to matters of domestic policy. They include for instance nominating the candidate for Prime Minister, appointing several other higher officials, and approving laws passed by the Riigikogu, the Estonian Parliament. 
The homepage of the President is set up in three languages: Estonian, English and Russian ${ }^{v}$. According to the Language Act, Estonian is the main language for communication in all spheres of public life. Therefore, it can be assumed that the Estonian website is the original one. It is the most detailed version of the three, containing in-depth information about the Republic of Estonia, the President (as institution), the official duties and media reports of the President. The English- and Russian-language websites are based on the Estonian content, but do not contain all the information that is available in Estonian. The sitemap of the Estonian-language website contains 30 pages, while the English-language website has 22 pages and the Russian-language website 19 pages. The Estonian-language website lists five main topics (President, Official duties, Media, Republic of Estonia, Estonia says thank you), while the English- and Russian-language websites list only four topics. The latter are missing the topic Estonia says thank you, which contains all the information about Estonian state decorations, the names of past recipients, and the form for nominating individuals for decorations. Nevertheless, most relevant information about state decorations is still available under the main topic Official duties, where readers can find a hyperlink to information on decorations in the English-language.

Although the number of sitemap entries in English (22) and Russian (19) is rather similar, there are more significant differences in the range of information provided. As the most important laws and legislation of Estonia have been translated into English and are available in the State Gazette, the English website contains almost the same number of hyperlinks to national legislation as the Estonian website. On the Russian website most of the hyperlinks are either missing or link to Estonian or English pages, meaning that only very few laws are translated into Russian. Apart from missing hyperlinks in the Russian website, the main topic President is comparable across all three languages. Differences are more significant in the main topic Official duties, which has six subtopics in the Estonian version, but only three and two in the English and Russian versions respectively. On the English and Russian websites, presidential visits in Estonia, proclaimed laws and issued decrees are missing completely. The Russian website does not even include presidential visits to other countries. The number of speeches delivered by the President in Estonia and other countries also varies: the website lists 167 speeches in the Estonian language, 93 in English and 36 in Russian. Most speeches in the English language have been delivered in other countries and probably in English. The speeches translated into Russian have been delivered mostly in Estonia at important national occasions. Apart from speeches, there is also a considerable difference in media coverage. The number of press releases, interviews and articles in the Estonian and foreign media is much higher in Estonian (550) than in English (296) and in Russian (98). The content of the main topic Republic of Estonia is similar in all languages. In brief, the most general information about the President is available in all three languages, but details about the activities of the President in Estonia and abroad are fully available in Estonian, partly in English and least of all in Russian.

Table 1 illustrates the similarities and differences between the three language versions. If the English or the Russian translation have the same content as the Estonian website and the hyperlinks lead to translated pages, this has been marked as "identical".

"Estonian webpage: https://www.president.ee/et/ (accessed: 28.12.2018). 
Table 1. The content of the website of the President of Estonia in Estonian, English, and Russian

\begin{tabular}{|c|c|c|c|c|}
\hline Main topics & Subtopics & Estonian website & English website & Russian website \\
\hline \multirow[t]{5}{*}{ President } & Biography & 1 page & Identical & Identical \\
\hline & $\begin{array}{l}\text { Oath of the } \\
\text { President }\end{array}$ & 1 page & Identical & Identical \\
\hline & Legal authority & $\begin{array}{l}1 \text { page with } 18 \text { links to } \\
\text { Estonian laws and } \\
\text { legislations }\end{array}$ & Identical & $\begin{array}{l}1 \text { page without } \\
\text { links }\end{array}$ \\
\hline & Patronage & $\begin{array}{l}9 \text { themes, all with links to } \\
\text { relevant pages }\end{array}$ & $\begin{array}{l}5 \text { themes, } 3 \\
\text { hyperlinks }\end{array}$ & $\begin{array}{l}5 \text { themes, } 1 \text { link } \\
\text { to the English } \\
\text { language page }\end{array}$ \\
\hline & Institutions & $\begin{array}{l}6 \text { themes, all with links to } \\
\text { homepages of } \\
\text { institutions }\end{array}$ & Identical & Identical \\
\hline \multirow[t]{6}{*}{$\begin{array}{l}\text { Official } \\
\text { duties }\end{array}$} & $\begin{array}{l}\text { Speeches in } \\
\text { Estonia and } \\
\text { abroad }\end{array}$ & $\begin{array}{l}\text { Full text of the most } \\
\text { recent speech in Tallinn } \\
\text { (20.12. 2018). } \\
9 \text { pages with } 167 \\
\text { speeches. }\end{array}$ & $\begin{array}{l}\text { Full text of the } \\
\text { speech in the Bank } \\
\text { of Estonia } \\
(17.12 .2018) . \\
5 \text { pages with } 93 \\
\text { speeches. }\end{array}$ & $\begin{array}{l}\text { Full text of the } \\
\text { speech on the } \\
\text { visit of Pope } \\
\text { Francis in } \\
\text { Estonia } \\
\text { (29.09.2018). } \\
2 \text { pages with } 36 \\
\text { speeches. }\end{array}$ \\
\hline & Visits in Estonia & 3 pages with 25 visits & Missing & Missing \\
\hline & $\begin{array}{l}\text { Visits to other } \\
\text { countries }\end{array}$ & 8 pages with 64 visits & $\begin{array}{l}6 \text { pages with } 44 \\
\text { visits }\end{array}$ & Missing \\
\hline & Laws & $\begin{array}{l}18 \text { pages with links to } \\
200 \text { laws }\end{array}$ & Missing & Missing \\
\hline & Decrees & $\begin{array}{l}4 \text { pages with hyperlinks } \\
\text { to } 60 \text { decrees }\end{array}$ & Missing & Missing \\
\hline & Decorations & $\begin{array}{l}1 \text { page with a hyperlink } \\
\text { to decorations } \\
\text { information system }\end{array}$ & Identical & $\begin{array}{l}\text { Identical, } \\
\text { hyperlink to } \\
\text { English page }\end{array}$ \\
\hline \multirow[t]{6}{*}{ Media } & Press releases & $\begin{array}{l}22 \text { pages with links to } \\
428 \text { press releases }\end{array}$ & $\begin{array}{l}11 \text { pages with links } \\
\text { to } 220 \text { press } \\
\text { releases }\end{array}$ & $\begin{array}{l}10 \text { pages with } \\
\text { links to } 91 \text { press } \\
\text { releases }\end{array}$ \\
\hline & Statements & $\begin{array}{l}1 \text { page with links to } 7 \\
\text { statements }\end{array}$ & Identical & $\begin{array}{l}1 \text { page with links } \\
\text { to } 4 \text { statements }\end{array}$ \\
\hline & $\begin{array}{l}\text { Interviews, } \\
\text { Articles in media }\end{array}$ & 7 pages with 122 links & $\begin{array}{l}4 \text { pages with } 76 \\
\text { links }\end{array}$ & $\begin{array}{l}1 \text { page with } 7 \\
\text { links }\end{array}$ \\
\hline & Bibliography & 1 page with 3 links & Identical & $\begin{array}{l}\text { Missing; instead } \\
\text { a media article } \\
\text { from 03.10.2016 }\end{array}$ \\
\hline & Videos & 2 pages with 16 videos & Identical & Identical \\
\hline & Photo album & $\begin{array}{l}28 \text { pages with } 147 \text { photo } \\
\text { albums }\end{array}$ & Identical & Identical \\
\hline \multirow[t]{5}{*}{$\begin{array}{l}\text { Republic of } \\
\text { Estonia }\end{array}$} & $\begin{array}{l}\text { Declaration of } \\
\text { Independence }\end{array}$ & 1 page & Identical & Identical \\
\hline & Constitution & $\begin{array}{l}1 \text { page with } 16 \text { links to } \\
\text { State Gazette }\end{array}$ & $\begin{array}{l}\text { Identical, but } \\
\text { without links }\end{array}$ & $\begin{array}{l}\text { Links to Russian } \\
\text { translation on } \\
\text { external source } \\
\end{array}$ \\
\hline & Symbols & 1 page with 3 links & Identical & $\begin{array}{l}\text { Identical, missing } \\
\text { are two links to } \\
\text { laws }\end{array}$ \\
\hline & Estonia & $\begin{array}{l}1 \text { page with } 10 \text { links to } \\
\text { government institutions }\end{array}$ & $\begin{array}{l}1 \text { page with } 11 \text { links } \\
\text { (only in English link } \\
\text { to State Gazette) }\end{array}$ & $\begin{array}{l}\text { Identical, but link } \\
7 \text { leads to } \\
\text { Estonian pages }\end{array}$ \\
\hline & $\begin{array}{l}\text { Heads of the } \\
\text { state }\end{array}$ & $\begin{array}{l}\text { Heads of state since } \\
1918 \text { with } 20 \text { links }\end{array}$ & Identical & Identical \\
\hline $\begin{array}{l}\text { State } \\
\text { decorations }\end{array}$ & 4 subtopics & 4 pages & Missing & Missing \\
\hline
\end{tabular}




\subsection{The University of Tartu's website}

The University of Tartu is the national university of Estonia, and the only classical university in the country, offering a range of programs in medicine, law, humanities and natural sciences. On its website, the university defines its mission as guarding and protecting the Estonian language and culture, where language policy issues have gained importance over the past few years as a result of internationalization and globalization. In order to strengthen its international education and research position, the university has set internationalization goals derived from the University's Strategic Plan for the period 2015-2020 (Strategic Plan, 2014). According to the strategic plan, the university aims for creating a motivating and attractive, internationally and culturally diverse learning and working environment. The university not only actively participates in international networks, but also develops existing curricula and creates new international ones. Instruction at courses at the University of Tartu is delivered in Estonian and English. The official teaching language for most bachelor's programs is Estonian. However, in the 2018-2019 academic year three programs (Business Administration, Science and Technology, and Medicine) were delivered fully in English. The number of master's programs with instruction in English is much higher (currently 24). To be able to implement its internationalization goals, the university has developed Englishlanguage support systems (e.g. advice regarding course planning, career counselling and psychological counselling) and an English-language website. In the academic year 2018/2019, 13,374 students (including 1,492 students from 90 foreign countries) studied at the University of Tartu (Kivistik \& Ress, 2018, p. 4). There are about 170 international academic and research staff at the university. According to a recent study at the University of Tartu, internationalization and operating on the global stage have resulted in an increased use of foreign languages (mostly English) by staff and students (Soler \& Vihman, 2018). The teaching and working environment is increasingly multilingual and the university must therefore provide information in other languages.

The website of the University of Tartu has been set up in three languages: Estonian, English and Russian. In contrast to the webpage of the President, where the sitemap was similar in all languages, the homepage of the University of Tartu shows larger differences between the languages and the content of the pages. The sitemap lists 439 pages in Estonian, 317 in English and only 21 in Russian. The topic menu contains 7 main topics on the Estonian and English website as opposed to 5 main topics on the Russian website. Table 2 illustrates the structure of the website and the number of pages (in brackets) in all languages.

Table 2: The structure of the website of the University of Tartu in Estonian, English, and Russian

\begin{tabular}{|l|l|l|}
\hline Topic menu & English website & Russian website \\
\hline Estonian website & Welcome Web (78 pages) & $\begin{array}{l}\text { About the university } \\
\text { (7 pages) }\end{array}$ \\
\hline Admissions (39 pages) & Admissions (42) & Admissions (7) \\
\hline Studies (188) & Studies (119) & Life-long learning (2) \\
\hline Life-long learning (81) & Research (7) & International (1) \\
\hline Research (9) & Business (1) & Contact (4) \\
\hline Entrepreneurship (1) & International (25) & \\
\hline Alumni (9) & About us (45) & \\
\hline About the university (112) &
\end{tabular}


Comparing the websites, we found that the content of information and the intended target group varies across all three websites. The Estonian homepage is the most detailed one and appears to target people with knowledge of the Estonian language and culture. The English website follows the internationalization goals of the university and is designed to be specifically aligned with the needs of international students and staff. Therefore, the English website is not a translation of the Estonian content but the information there is tailor-made. It contains a special main topic Welcome Web, which is not available in Estonian or Russian and is meant for international students and staff who consider coming to Estonia and Tartu. Besides providing information about the university it also serves as a promotional tool. Both the English and the Russian website have the main topic International, but the content is very different. The English website provides a thorough overview of the international goals of the university, the international partners and collaborative networks, student and academic staff international mobility options, as well as international events. The Russian website offers localized information, in the sense that it lists only a few Russian partner universities and names some collaborative networks. In general, the Russian website provides only very basic information about the university and does not appear to be updated very often, as the latest news on the front page is dated more than six months prior to the time of analysis. The reason for the lack of Russian-language information is probably related to the fact that none of the programs at the university are taught in Russian only. The official teaching language for most programs is Estonian - even students who are specializing in Russian Language and Literature are expected to complete general courses in Linguistics and Literature in Estonian. Applicants to all bachelor's and master's level programs with instruction in English must provide proof of English language proficiency. Staff members must also be proficient in both Estonian and English.

\section{Conclusion}

The three levels of translation policy as outlined by González Núñez (2016) are also identifiable in the Estonian cases studied here and have as such proven to be applicable. After Estonia regained its independence in 1991, language and translation management in the republic has been clearly marked by changes in society during the Soviet period. While the country was almost homogeneously Estonian from a cultural point of view prior to World War II, this has significantly changed due to the influx of Russian speakers and russification policy in Soviet times. Since Estonia regained its independence, Russian speakers have comprised roughly one third of the population. Despite the lack of official status, Russian is still widely used in the fields of trade and services, advertising, media, and education. Many public authorities also have Russian versions on their websites, but there are no official Russian translations of legislation.

The legal document that mainly regulates the priority position of Estonian in administration and public service is the Language Act. Translation management starts from the basic concept of Estonian as the default option. However, the Act reflects flexibility for the use of English (for international purposes) and Russian (so as to partly accommodate Russian speakers). Translation beliefs under these circumstances are conditional and not absolute. Despite the official prioritized status of Estonian in Estonia, approximately one million Estonian native speakers remain in a (culturally and politically) 
vulnerable position in relation to English and Russian when ongoing globalization is taken into account. Power relationships between languages clearly play a role in determining the flexibility of a translation policy.

Translation practice in the cases of the websites examined is developed along similar lines. On the one hand, the preferential position of Estonian is unmistakable, on the other hand, pragmatism allows for English and Russian language versions. However, these versions are often not the result of translation proper. The English language versions are tailored to international needs, whereas the Russian language versions are more often localized for the Russian audience - this is for instance the case when speeches have a clear national interest, or where it is referred specifically to Russian partner universities and networks. This also includes quite important quantitative differences between the amount of information made available in the two foreign languages: much more in English than in Russian. English also has an international public relations function, whereas the use of Russian is much more limited.

Based on the results of the case studies discussed in this article, it can be stated that Estonian translation policy is pragmatic and cautious at the same time. It shows openness to accommodate an international audience and, in some cases, to provide localized information for a Russian-language audience, although not to the same extent. At the same time, the priority of Estonian is obvious also in the translation practices. This interplay between translation management, practices and beliefs is co-determined by the power relationships between the languages involved - prioritizing Estonian, the 'small' but majority language, with specific and more tailored roles for English and Russian, the internationally more significant languages.

Future research could start from the above hypothesis when studying other cases of institutional communication and translation, especially in the Baltic states, but possibly also in different contexts marked by interlingual and intercultural power relationships. Furthermore, the role of the procedures and agents in the institutions producing the translated texts could be investigated in more detail.

\section{Acknowledgement}

This work was supported by the University of Tartu Astra Project Per Aspera and grant number PHVLC19917.

\section{References}

DPEL. (2011). Development plan of the Estonian language 2011-2017. English translation by Enn Veldi. Tallinn: Eesti Keele Sihtasutus. Retrieved from https://www.hm.ee/ sites/ default/ files/ eestikee le are ngukavainglise.indd_.pdf

Estonian Foreign Languages Strategy 2009-2015. Retrieved from https:/ / www. hm .ee/sites/default/files/evks.pdf

Gipper, A., \& Dizdar, D. (2015). Einleitung: Übersetzung als Konstruktionselement nationaler Identität. In D. Dizdar, A. Gipper \& M. Schreiber (eds.), Nationenbildung und Übersetzung (pp. 7-16). Berlin: Frank \& Timme.

González Núñez, G. (2016). On translation policy. Target, 28(1), 87-109.

Heilbron, J., \& Sapiro, G. (2007). Outline for a sociology of translation: current issues and future prospects. In M. Wolf \& A. Fukari (eds.), Constructing a sociology of translation (pp. 93-107). Amsterdam \& Philadelphia: John Benjamins.

Kivistik, K. \& Ress, K. (2018). Tartu Ülikooli töötajate keelehoiakud 2018. aastal. Uuringuaruanne. Tartu: Tartu Ülikool. Retrieved from https://siseveeb.ut.ee/sites/

Translation \& Interpreting Vol. 12 No. 2 (2020) 
default/files/siseveebi_failid/tu_tootajate_keelehoiakud_2018_uuringuaruanne_1 .pdf

Language Act. (2011). RT I, 18.03.2011, 1. Retrieved from https://www. riigiteataja. ee/en/eli/512012016001/consolide.

Meylaerts, R. (2011). Translational justice in a multilingual world: An overview of translational regimes. Meta, 56(4), 743-757.

Monticelli, D. (2015). (Trans)forming national images in translation: The case of the "Young Estonia" movement. In L. van Doorslaer, P. Flynn \& J. Leerssen (eds.), Interconnecting Translation Studies and Imagology (pp. 277-297). Amsterdam \& Philadelphia: John Benjamins.

Ožbot, M. (2012). Small cultures: construction of identity through translation. In M. Snell-Hornby \& M. Kadrić, Die Multiminoritätengesellschaft (pp. 103-109). Berlin: SAXA.

Rannut, M. (2004). Language policy in Estonia. Noves SL. Revista de sociolingüística 1(2). Retrieved from http:// www.gencat.cat/ llengua/noves/noves/hm04 primavera-estiu/docs/rannut.pdf

Rumford, C. (2006). Theorizing borders. European Journal of Social Theory, 9(2), 155 169.

Sapiro, G. (2016). How do literary works cross borders (or not)? A sociological approach to world literature. Journal of World Literature, 1, 81-96.

Schäffner, C. (2016/2008). Does translation hinder integration? In S. Baumgarten \& C. Gagnon (eds.), Translating the European House: Discourse, ideology and politics - selected papers by Christina Schäffner (pp. 244-263). Newcastle upon Tyne: Cambridge Scholars Publishing. [original version in German 2008]

Soll, M., Salvet, S., \& Masso, A. (2015). Changes in language policy in Estonia. Trames, 19(69/64), 3, 221-247. Retrieved from http://www.kirj.ee/public/trames _pdf/2015/issue_3/trames-2015-3-221-247.pdf

Soler, J., \& Vihman, A. (2018). Language ideology and language planning in Estonian higher education: Nationalising and globalising discourses. Current Issues in Language Planning, 19:1, 22-41, DOI: 10.1080/ 14664208.2017.1281039.

Statistics Estonia. (2012). Population and Housing Census 2011. Retrieved from https://www.stat.ee/64629

Strategic Plan. (2014). Strategic Plan of the University of Tartu for 2015-2020. Retrieved from https://www.ut.ee/en/university/strategy.

The Constitution of the Republic of Estonia. (1992). RT 1992, 26, 349. Retrieved from www.riigiteataja.ee/en/eli/521052015001/ consolide

van Doorslaer, L. (2006). Ideologisch inspiriertes Idyll: deutsche Übersetzungen der flämischen Literatur unter der Flamenpolitik des Ersten Weltkriegs. In M. Wolf (ed.), Übersetzen, $\quad$ translating, traduire: towards a 'social turn'? (pp. 307316). Münster: LIT.

van Doorslaer, L. (2018). Turning minorities and majorities upside down. In: S. Baumgarten \& J. Cornellà-Detrell (eds.), Translation and global spaces of power (pp. 39-58). Bristol: Multilingual Matters.

van Es, N., \& Heilbron, J. (2015). Fiction from the Periphery: How Dutch writers enter the field of English-language literature. Cultural Sociology, 9(3), 296-319. 